AgNiESZKA RumianOWSKA

ORCID 0000-0001-5508-8781

Mazowiecka Uczelnia Publiczna

w Płocku

\title{
THE QUEST FOR AUTHENTICITY AND SELF-DISCOVERY IN EDUCATION WITH SPECIAL ATTENTION PAID TO LANGUAGE EDUCATION
}

\begin{abstract}
AвSTRACt. Rumianowska Agnieszka, The Quest for Authenticity and Self-discovery in Education with Special Attention Paid to Language Education [Poszukiwanie autentyczności i odkrywanie samego siebie w edukacji, ze szczególnym uwzględnieniem edukacji językowej]. Studia Edukacyjne nr 59, 2020, Poznań 2020, pp. 273-284. Adam Mickiewicz University Press. ISSN 1233-6688. DOI: 10.14746/se.2020.59.17

The purpose of the article is to contribute to the discussion about the relevance of existential issues in contemporary education. The analyses presented in the paper are related to the problems of self-reflection, self-questioning and the process of spiritual and moral development of human beings. Firstly, the author begins by depicting the meaning of human existence in the light of philosophy. What is at issue here is a question of being oneself, recognizing personal truth and finding one's own voice as opposed to being inauthentic or fleeing from oneself. Special attention is paid to the language as an essential, constitutive element of being. Secondly, the article attempts to consider some educational implications resulting from the deep ontological relationship between human beings and language. Describing them, the author indicates that ignoring vital questions in language education contributes to spiritual vacuity in the lives of young people and reduces educational thinking merely to instrumental, pragmatic problems concerned with qualification and transfer of communicative skills.
\end{abstract}

Key words: language; existentialism, education, authenticity, dialogue

\section{Introduction}

"Who would I be, if I could be, what would I say, if I had a voice, who says this, saying it's me". ${ }^{1}$ Beckett's words seem to provide an interesting inspiration to consider the problem of education with special attention paid to language

\footnotetext{
${ }^{1}$ S. Beckett, Texts for nothing, London 1999, p. 22.
} 
education. Beckett appears to persuade us that the task of every human being is to move towards their possibilities, to project and permanently define their own existence. A human being can exist only through self-invention, self-interpretation and self-projection. Therefore, they can question and take possibilities of being or being themselves, being authentic or inauthentic. Moreover, they can choose either genuine or false modes of existence. Indeed, there is no any other option as to choose between fleeing from oneself and being oneself.

A similar view of human existence is striking in Heidegger`s thought. According to Heidegger ${ }^{2}$ being is a task, which means not merely existing, but existing fully and genuinely. Thus, the human being can fall into groundlessness, given patterns, idle talk or a kind of conformism, however at the same time they can make themselves authentic. In other words, they can lose or gain themselves and become more independent. Authenticity means nothing else as an ability to develop the personal truthfulness with oneself and the openness to being. Heidegger claims that most people are inauthentic because they are absorbed and concealed in the life and in the world of Everyman which is narrow-minded and stereotypical. Man strives to be like other people, to speak like others or to have similar opinions, beliefs or points of view. The choice of average, anonymous and superficial existence means nothing beyond the fact, that "everyone is the other and no-one is himself". ${ }^{3}$

There is general consensus that an individual is situated in socially and culturally determined contexts, however it should be also noted that it has always more or less the ability to determine and to define its life on the basis of this social and cultural background. In other words, every human being is thrown into world and wrapped up in different, social structures, but at the same time it is to a certain extend free to project their life in harmony with themselves. The significant point here it is to recognise one`s personal truth. Accordingly, as Kierkegaard ${ }^{4}$ suggests, "even the richest personality is nothing before he has chosen himself, and on the other hand even what one might call the poorest personality is everything when he has chosen himself; for the great thing is not to be this or that but to be oneself, and this everyone can be if he wills it". All that shows why it is so utterly unhelpful and flawed to view, measure, and assess other humans merely in context of their skills, knowledge and proficiency.

Returning to Beckett, it can be stated that regardless of whether a human being can choose themselves, whether they have a voice or not, whether they speak as themselves or repeat foreign sentences, one thing is certain: they cannot stop asking about themselves. And yet, the question about oneself should

\footnotetext{
${ }^{2}$ M. Heidegger, Being and Time, transl. by J. Stambaugh, New York (1927) 2010.

${ }^{3}$ Ibidem, p. 169.

${ }^{4}$ S. Kierkegaard, Either-Or, transl. by W. Lowrie, New York (1843) 1959, p. 181.
} 
be seen as the starting point of education with special attention paid to language education. In addition, it can happen that an individual does not not see any sensible and valuable aim in life, it can happen that they face some existential problems with themselves or that they have nothing to say, but it is completely impossible that they do not question, do not think about themselves or do not confront themselves and their own life.

\section{Existential perspective on education}

It is difficult to speak about language education and language development without determining what education is. Therefore, before discussing the language conception in education I want briefly to indicate what is meant by this term and propose a theoretical perspective from which this term can be considered. A special position of thinking about education is occupied by existentialism, which is named as a theory of human development, a philosophy of being, existence or life. In general, existentialism is viewed as a protest against traditional metaphysics, mechanization of human being, calculative thought and as a dissent form the dehumanizing values of contemporary culture, which contributes to self-estrangement, language-alienation and loneliness. ${ }^{5}$ The peculiarity of existentialism lies in the assumption that a human being is a creator whose task is to choose oneself, to authenticate one's existence and to develop one's own potentialities of being. In an obvious way that raises the question to the extent to which existentialism can be taken into account by the problem of education.

Kierkegaard asks as well as suggests: "What, then, is education? I believe it is the course the individual goes through in order to catch up with himself". ${ }^{6}$ In his opinion the key problem of the education is the ability to be a person, to be self which is connected with spiritual development of human being. He points out to the best in individuals which can be brought out in the process of education. The question is to make students aware of what is already in them, to encourage them to develop their uniqueness, their intellectual, spiritual, social and emotional potentialities. In this sense education corresponds with personal and integral growth, self-consciousness and reflexion. What counts is the infinite development of individual and their creativity. Obviously, that development does not take place in a vacuum. On the contrary, it goes on in relation to the world, others and oneself. This is why, the ethical and moral aspects of human life with others must be emphasised and taken into account

\footnotetext{
${ }^{5}$ P. Tillich, The Courage to be, Yale 2014, p. 139.

${ }^{6}$ S. Kierkegaard, Fear and Trembling and Repetition, transl. by H.V. Hong, E.H. Hong, New Jersey (1843) 1983, p. 46.
} 
in the educational context. Because ontologically a being is always a being with and cannot be a self without others, special attention must be drawn to dialogical education.

On the basis of the foregoing considerations it can be concluded that the aim of education in existential perspective is to encourage the individuals for self-formation, to inspire them to become themselves, to become more reflexive, humble and finally to draw out of them which is in them. It is a matter of finding their own voice and personal truth by taking responsibility for themselves and their acts. Students should expend horizons and develop themselves in ways that neither they nor their teachers can foresee. All that shows why it does not make any sense to treat individuals merely as human resources or human capital. It is simply not sufficient to reduce education to measuring proficiently or developing basic skills and literacy. In this light education is not just the question of how to transmit knowledge or how to prepare people for employment or citizenship but also how to prepare them for meaningful life. ${ }^{7}$

\section{On the essence of language}

The central issue for becoming a human being and for self-forming is a language which constitutes a human being. Heidegger indicates that it is the language that speaks, not us. ${ }^{8}$ Therefore, a language primarily belongs to being not to us. It can also be stated that being speaks to one through language. According to Heidegger language is the "house of being". To put it differently, we live in the language as in the "house of being". Heidegger ${ }^{9}$ stresses that our experience to language as well as our experience to being is not "of our own making". He explains it as follows: "Language speaks not. Man speaks insofar as he responds to language". Thus, the point is to follow, to be guided and to hearken. Language speaks as itself not when the solution to a problem is presented or a proposal is enunciated, not when we use previously prepared words but rather when we look for words, when we rise to speak and finally when we have a voice. In other words, language speaks as itself when there is a crisis, when critical thinking occurs and ultimately when the situation brings meaning for the individual. ${ }^{10}$ Every time, when the human being faces extreme

\footnotetext{
${ }^{7}$ M. Nussbaum, Not For Profit. Why Democracy Needs the Humanities, Princeton - Oxford 2016, p. 9.

${ }_{8}$ M. Heidegger, Poetry, Language, Thought, transl. by A. Hofstadter, New York (1951) 1971, p. 216.

${ }^{9}$ Ibidem, p. 57.

${ }^{10}$ M. Heidegger, On the way to language, transl. by P. Hertz, J. Stambaugh, New York (1959) 1971, p. 59.
} 
situations, exceptional and unusual problems or enters into dialogical relations with others, language speaks as itself and speaks by saying. Heidegger ${ }^{11}$ indicates that saying and speaking do not mean the same and therefore both terms are not identical because "one can speak, speak endlessly, and it may all say nothing. As opposed to that, one can be silent, not speak at all, and in not speaking say a great deal". To "say" something in the Heideggerian sense means "to show, to let something appear, let it be seen and heard". When the individual treats other people and situation in this way, they become part of his or her inner spiritual world. On the contrary, when it does not happen, he or she repeats sentences or words by heart and is not able to express ideas in his or her own words. Therefore, the question is to look for words and not merely for "suitable" and "appropriate" phrases.

In summary, in ontological perspective the essence of language can be seen not only as an expression of internal feelings, experiences or as an activity of humankind. Heidegger says that it can be no longer considered

general notions like energy, activity, labour, force of spirit, view upon the world or expression, under which we might subsume language as a particular instance of this or that universal. Instead of explaining language as this or that, and thus fleeing from it, the way to language wants to let language be experienced as language. ${ }^{12}$

When the language is understood only as an instrument, as a mere means of expression and communication this interpretation is from logical and psychological point of view correct but is not true in the ontological sense because it does not capture the essence of language. This conception is not false, but it obscures and masks the essence of language, which should be analysed as a means by which being discloses itself. In its shortest formula, the approach of Heidegger calls into question many traditional assumptions underlying understanding of language and therefore language education.

What is common for Heidegger and Jaspers is making a clear distinction between the public language, idle talk or "sign language" and the so called "word language" which itself is authentic. Sign-language is generally understandable, logical and communicable, however, it is at the same time often obscured by public realm. The idle talk, the term coined by Heidegger, expresses the same meaning and relates to shallow understanding of itself. Instead of genuine communication, being itself and critical thinking the human being falls into idle talk, curiosity, gossip and ambiguity. ${ }^{13}$ There are established games, strict

\footnotetext{
11 Ibidem, p. 122.

12 M. Heidegger, Basic writings: From Being and Time (1927) to the Task of Thinking, transl. by D.F. Krell, London (1964) 1978, p. 406.

13 M. Heidegger, Being and Time.
} 
roles about what counts, what is acceptable and what is not. In other words, idle talk relates to what must be known in order to be what is today named "in".

At this point special attention should be also paid to the role of mother tongue in the process of self-forming. There are numerous definitions of mother tongue and there is not any of universal acceptance. The language of origin, community language, quasi native language and first language are often used interchangeably. I limit my emphasis to the assumption that firstly, mother tongue is acquired at home as the first language, secondly there is the personal, historical connection to language through family or also educational interactions, thirdly linguistic proficiently in the language is achieved and fourthly man is strongly dominant in this language. It is important to point out that mother tongue is part "of learners life-worlds, integral to the framework of interpretative resources, that they bring to learning". ${ }^{14}$ In this language prayers are done and childhood poems are recited, books are read, academic papers are prepared or jokes are told. ${ }^{15}$

Jaspers suggests that mother tongue is the source and the second language is communicative experience. In his opinion, a human being lives definitely only in one language. The mother tongue touches the deepest structures of our existence. Of course, if a human being limits itself willingly only to one language, it is not beneficial for it because if one learns other languages he or she becomes more and more aware of his or her own language. However, Jaspers emphasizes that speaking other languages does not mean yet that an individual understands the substance of the original language. Arendt makes a similar point by arguing that there is no substitution for the mother tongue. When she was in exile, she said:

We lost our language, which means the naturalness of reactions, the simplicity of gestures, the unaffected expression of feelings. In German I know a large part of German poetry by heart; the poems are always in the back of my mind. I can never do that again. I do things in German that I would not permit myself to do in English. The German language is the essential thing that has remained and that I have always consciously preserved. ${ }^{16}$

${ }_{14}$ A. Scarino, The Place of Heritage Languages in Languages Education in Australia: A Conceptual Challenge, [in:] Rethinking Heritage Language Education, Cambridge 2014, p. 75.

${ }_{15}$ The role of the first language in the process of self-forming and self-development has been confirmed in psychological studies as well. Several researchers suggest that the first language is perceived as more emotional because emotional words in the first language are stored more deeply than emotion words in the second language. Emotionality concerned with the first language is experienced more strongly than emotionality connected with the second language (A. Pavlenko, Bilingual Selves, [in:] Bilingual Minds: Emotional Experience, Expression, and Representation, Ed. A. Pavlenko, Toronto 2006, p. 20-23).

${ }^{16}$ H. Arendt, Fernsehgespräch mit Günter Gaus, [in:] Ich will verstehen: Selbstauskünfte zu Leben und Werk, Munich (1964) 2005, p. 59. 
Furthermore, she adds that she speaks English proficiently, but she finds it as the language in which one cliché chases another and in which she is not able to speak and write so idiomatically as in Germen.

\section{Between the self and the other}

Among several thinkers like Levinas, Buber or Jaspers it is a wildly held belief that one becomes genuinely a person only by entering into relation with another person. In particular, Levinas ${ }^{17}$ makes a critique of the Heidegger`s concept according to which humans are interested only in their own being. He points out metaphorically that "dasein in Heidegger is never hungry". What Levinas shares with Heidegger's approach is the contention that it is the language that speaks. However, in his opinion the use of language almost always relates to others. The face-to face-relationship is realised through language which "originates" in the dialogue with others. What counts here, is the deeply ethical encounter between the self and the other as well as the question of responsibility. Levinas ${ }^{18}$ claims that "to speech, is to make the world common, to create commonplaces. Language does not refer to the generality of concepts, but lays the foundation for a possession in common (...) It is what I give, the communicable, the thought, the communication". The genuine communication can be achieved when an individual puts their world into words and offers it to the other. The fundamental principle underlying such a communication is, of course, equality of communicative partners. Therefore, if one makes the other play roles in which he or she does not recognise himself or herself, communication turns into violence.

Jaspers makes a similar point when he suggests that self-being is only real in communication with another self-being. It means that human being cannot be themselves merely by themselves. The only way of self-realisation is communication in which an individual wants to be manifest and transparent. Jaspers ${ }^{19}$ explains it as follows: "Alone, I sink into gloomy isolation, only in community with others can I be revealed in the act of mutual discovery". The point is to discover oneself as separate by entering into relationship with others. In this context Jaspers distinguishes two types of communication: social, objective, pure functional communication and existential communication. In the first case, the "everyday" communication is caused by physical needs,

${ }^{17}$ E. Levinas, Totality and Infinity: An Essay on Exteriority, transl. by A. Lingis, Pittsburgh 1969, p. 134.

${ }^{18}$ Ibidem, p. 76.

${ }^{19}$ K. Jaspers, On my own Philosophy, [in:] Existentialism from Dostoevsky to Sartre, Ed. and transl. by W. Kaufmann, New York (1941) 1975, p. 147. 
spontaneous emotions and characterised by logical and pragmatic thinking. All that has nothing to do with existential communication which is reached when two humans reveal themselves to each other in their individuality. ${ }^{20}$ Such communication is based on authentic personal relationship, trust and deep mutual understanding, which deepen the relationship and contribute to personal growth. Moreover, each person maintains his or her uniqueness and retains their own potential. Jaspers ${ }^{21}$ emphasises that "I cannot be myself unless the other wants to be himself; I cannot be free unless he is free; I cannot be sure of myself unless I am sure of him. In [existential] communication I feel responsible not only for myself but for the other, as if he were I and I were he; I do not feel it set in until he meets me half-way". This way of understanding of the relationship between self and others has been articulated by Buber as well. He argues that it is a dialogue in which the entities recognise each other as equal, have in mind the others in their present and particular being and turn to them with the intention of establishing a living mutual relationship between themselves and the other participant. ${ }^{22}$ In this light dialogue occurs not merely in the psychological, emotional or physical realm, but rather in the spiritual space.

Most what has been written on language and communication of existential point of view tends to highlight and confirm that the most appropriate space to have a voice and to speak as oneself is the dialogical, inter-human relationship that encourages each partner for authentic existence. The question is now if such a dialogue and existential communication are possible in the context of education. Of course, the idea may sound idealistic and it is not easy to translate ideals into the action, but what really counts are tolerance and patience, the need to preserve self-respect and respect for the otherness of others, the capacity to listen and willingness to understand other people. Even during broken communication, common understanding is still possible - says Gadamer. ${ }^{23}$

\section{Language education}

All the issues highlighted above are deeply relevant to language education. The question now is what the problems mean for language education? Without doubt, the foregoing considerations put forward several arguments against mechanical and objective way of language education. All that ex-

\footnotetext{
${ }^{20}$ K. Jaspers, Philosophy, transl. by E.B. Ashton, Chicago (1932) 1969, p. 48.

${ }^{21}$ Ibidem, 1969, p. 52.

${ }^{22}$ M. Buber, Between Man and Man, transl. by R.G. Smith, London (1947) 1961, p. 37.

${ }^{23}$ H-G. Gadamer, Education is Self-Education, Journal of Philosophy of Education, 2001,
} 4(35), p. 533. 
plains why it is so utterly insufficient to develop only the communicative skills, grammar or vocabulary. Surprisingly, the quest for supporting personal development, self-reflection and self-forming in the process of language education is in fact not new. In particular, Pestalozzi stressed the essential role of language for self-development and combated: "all scientific teaching which is analysed, explained and dictated by men who have not learnt to think and speak with harmony with the laws of nature" ${ }^{24}$ Gadamer ${ }^{25}$ repeats a similar thought about a hundred fifty years later, arguing that "human capabilities are the ones of stress if one is to educate and to cultivate oneself". It means that emotional, cognitive and social abilities as well as life experiences should have a higher relevance in language education.

According to Essen ${ }^{26}$ - a German teacher and researcher of the twentieth century - the aim of language education is to facilitate learners to increase their self-understanding, to encourage them to realize and project themselves in relationship with the word, themselves and other people. The task is to reveal their linguistic and natural potential in this respect and to strengthen their own resources. Everything is already in the pupil. What the teacher has to do is to encourage him or her to form it and to inspire him or her to have courage to be and to develop his or her uniqueness. What the entity needs is on the one hand reflection and self-consciousness and on the other hand dialogical genuine, authentic participation in the process of education. In this regard, it seems beneficial to work with literature, poems, drama, music, pictures or lyric. The crucial role is also played by creative writing. The necessity of transformation of visual, emotional, spiritual impressions, feelings and experiences into different linguistic forms make students think creatively and as result produce subjective texts and their own individual utterances. ${ }^{27}$ The next appropriate way to problematize their own existential situation, to facilitate students to discover who they really are and to help them gain their own voice in the world is use of popular culture in language education..$^{28}$ Nowadays, popular culture is the most important window through which young people view the world and the dominant space on whose basis they construct their identity. The aim is certainly neither to assess nor to glorify popular culture. The significant point is to help the entity to deal with the most troubling and existential question of

\footnotetext{
${ }^{24}$ H. Pestalozzi, Schriften zur Menschenbildung, Basel (1857) 1946, p. 48.

${ }^{25}$ H-G. Gadamer, Education is Self-Education, p. 537.

${ }^{26}$ E. Essen, Bildung durch Sprachbewusstsein und sprachliches Gestalten, Frankfurt am Main 2002, p. 35-42.

${ }_{27}$ K. Hellwig, Sprachlich handeln- von Medium zu Medium. Prozessorientiert-kreatives Lernen im Englischunterricht durch Sprach-, Bild- und Musik-,,Texte“, [in:] Probleme der Schreibentwicklung im Fremdsprachenunterricht, Ed. J. Iluk, Katowice 1997, p. 109.

28 A. Rumianowska, Der Einsatz der Populärkultur im Fremdsprachenunterricht. Eine empirische Untersuchung am Beispiel von Musikvideoclips, Deutsch als Fremdsprache, 2009, 46(1), p. 38-44.
} 
"who I am" and therefore to become more aware of themselves. ${ }^{29}$ In this respect everyday life provides an opportunity to write, speak and read in a creative, constructive as well as deconstructive way. The role of reflexion, creativity and self-consciousness should also be indicated. Many contemporary researchers argue that capability of language use depends on the level of cognitive ability attained during the education process. ${ }^{30}$ The cognitive growth is connected with the level of academic skills in writing and reading. Therefore, lingual proficiency and fluently are not the same as producing complex language sentences, structures or understanding complex, abstract concepts or using complex idioms. In order to strengthen the language potentialities and to develop higher level thinking in language students need to learn in a rich literary environment and in a meaningful context. Moreover, because the cognitive ability in the mother tongue is transferred into the second language, it is particularly beneficial to continue the education in the first language, especially when the learners move in another country. ${ }^{31}$

It is important to note that the existential-ontological turn in language education is not possible without activating the whole individual, its mind and spirit, its intellectual, spiritual and emotional potentialities. To engage the whole human being means to relate to what they know, how they act with others, who they are and what they say. Buber ${ }^{32}$ reminds us that our aim as teachers is not merely to eliminate the negative behaviour, mistakes of the students and other obstacles or to see the worst in the man but rather to see the best in the other. The role of teacher consists in "letting learn" by creating space and opportunities for learning, in being open to student's needs and helping them to come into their own. At this point it should also be indicated that such language education can be realised only in personal, dialogical relationship between the students and the teacher. The dialogue means here the total rejection of manipulation, prejudices or playing any roles. In general, it is a call for meaning, dialogical self and authenticity and at the same time protest against categorisation, empty rationality and technical, pragmatic conception of language education.

${ }^{29}$ P. Freire, H. Giroux, Pedagogy, Popular Culture and Public life: An introduction, [in:] Popular Culture, Schooling and Everyday Life (Critical Studies in Education), Eds. H. Giroux, R. Simon, Toronto 1989.

${ }^{30}$ J.B. Carroll, Human Cognitive Abilities. A Survey of Factor-Analytic Studies, Cambridge 1993, p. 193; J. Cummins, BICS and CALP: Empirical and Theoretical Status of the Distinction, [in:] Encyclopaedia of Language and Education, volume 2, Eds. B. Street, N.H. Hornberger, New York 2008, p. 71-83.

${ }^{31} \mathrm{~J}$. Cummins, The role of primary language development in promoting educational success for language minority students, [in:] Schooling and Language Minority Students: A Theoretical Framework, Los Angeles 1981.

${ }^{32}$ M. Buber, Between Man and Man. 


\section{Concluding Remarks}

From the existential point of view, being is never finished, complete and static. Quite the contrary, it permanently develops itself in relation with itself, the world and through dialogue with others. The significant point is to recognize that a being is "being possible" which means that it has not only its limitations but also possibilities. Therefore, it can follow the crowd and blindly accept the public conceptions or search for its own voice and own spirituality. In this light, particular attention must be given to the language, especially the mother tongue which is strictly connected with the problem of being. Language gives man an insight into being and constitutes the way man relates to the world. Therefore, it cannot be understood instrumentally or interpreted merely as a means of pragmatic communication or transmission of information. In the face of that assumption it becomes clear that language education must by connected with existential questions, self-development and self-forming, which is fused with creativity, risk, self-consciousness, dialogue with others and choice. The point is, after all, to make a person think not only about what he or she says but also why he or she says it. It is not a question of filling the gap between itself and others within random words or using the language in an abstract way without reference to concrete experiences. That type of speech does not have anything to do with the essence of the language and does not make it easy to look at the world in an alternative way or to live a meaningful and authentic life.

\section{BIBLIOGRAPHY}

Arendt H., Fernsehgespräch mit Günter Gaus, [in:] Ich will verstehen: Selbstauskünfte zu Leben und Werk, Piper Verlag, Munich (1964) 2005.

Beckett S., Texts for nothing, John Calder, London 1999.

Buber M., Between Man and Man, transl. by R.G. Smith, Collins, London (1947) 1961.

Carroll J.B., Human Cognitive Abilities. A Survey of Factor-Analytic Studies, Cambridge University Press, Cambridge 1993.

Collier V.P., Thomas W.P., Reforming education policies for English learners means better schools for all, The State Education Standard, 2002, 3(1).

Cummins J., The role of primary language development in promoting educational success for language minority students, [in:] Schooling and Language Minority Students: A Theoretical Framework, Evaluation, Dissemination and Assessment Center California State University, California State Department of Education, Los Angeles 1981.

Cummins J., BICS and CALP: Empirical and Theoretical Status of the Distinction, [in:] Encyclopaedia of Language and Education, volume 2, Eds. B. Street, N.H. Hornberger, Springer Science + Business Media LLC, New York 2008.

Dall`Alba G., Barnacle R., An ontological turn for higher education, Studies in Higher Education, 2007, 32(6). 
Essen E., Bildung durch Sprachbewusstsein und sprachliches Gestalten, Peter Lang, Frankfurt am Main 2002.

Freire P., Giroux H., Pedagogy, Popular Culture and Public life: An introduction, [in:] Popular Culture, Schooling and Everyday Life (Critical Studies in Education), Eds. H. Giroux, R. Simon, Bergin \& Garvey Publishers, Toronto 1989.

Gadamer H-G., Education is Self-Education, Journal of Philosophy of Education, 2001, 4(35).

Gadamer H-G., The Incapacity for Conversation, Continental Philosophy Review, (1972) 2006, 39.

Heidegger M., Poetry, Language, Thought, transl. by A. Hofstadter, Harper and Row, New York (1951) 1971.

Heidegger M., On the way to language, transl. by P. Hertz, J. Stambaugh, Harper and Row, New York (1959) 1971.

Heidegger M., Basic writings: From Being and Time (1927) to the Task of Thinking, transl. by D.F. Krell, Routledge, London (1964) 1978.

Heidegger M., Being and Time, transl. by J. Stambaugh, State University of New York Press, New York (1927) 2010.

Hellwig K., Sprachlich handeln-von Medium zu Medium. Prozessorientiert-kreatives Lernen im Englischunterricht durch Sprach-, Bild- und Musik-,,Texte“, [in:] Probleme der Schreibentwicklung im Fremdsprachenunterricht, Ed. J. Iluk, Wydawnictwo Uniwersytetu Śląskiego, Katowice 1997.

Jaspers K., Way to Wisdom: An Introduction to Philosophy, transl. by R. Mannheim, Yale University Press, New Haven - London 1951.

Jaspers K., Philosophy, transl. by E.B. Ashton, University Press, Chicago (1932) 1969.

Jaspers K., On my own Philosophy, [in:] Existentialism from Dostoevsky to Sartre, Ed. and transl. by W. Kaufmann, Meridian, New York (1941) 1975.

Kierkegaard S., Either-Or, transl. by W. Lowrie, Doubleday, New York (1843) 1959.

Kierkegaard S., Fear and Trembling and Repetition, transl. by H.V. Hong, E.H. Hong, Princeton University Press, New Jersey (1843) 1983.

Levinas E., Totality and Infinity: An Essay on Exteriority, transl. by A. Lingis, Pennsylvania: Duquesne University Press, Pittsburgh 1969.

Michelman S., The A to Z of Existentialism, Plymouth: Scarecrow Press, Lanham, Toronto 2010.

Nussbaum M., Not For Profit. Why Democracy Needs the Humanities, Princeton University Press, Princeton - Oxford 2016.

Pavlenko A., Bilingual Selves, [in:] Bilingual Minds: Emotional Experience, Expression, and Representation, Ed. A. Pavlenko, Clevedon, Bufallo, Multilingual Matters ITD, Toronto 2006.

Pestalozzi H., Schriften zur Menschenbildung, Birkhäuser, Basel (1857) 1946.

Reynolds J., Understanding Existentialism, Routledge, London - New York 2014.

Rumianowska A., Der Einsatz der Populärkultur im Fremdsprachenunterricht. Eine empirische Untersuchung am Beispiel von Musikvideoclips, Deutsch als Fremdsprache, 2009, 46(1).

Samway K., McKeon D., Myths and Realities. Best Practices for English Language Learners, Heinemann, Portsmouth 1999.

Scarino A., The Place of Heritage Languages in Languages Education in Australia: A Conceptual Challenge, [in:] Rethinking Heritage Language Education, Cambridge University Press, Cambridge 2014.

Tillich P., The Courage to be, Yale University Press, Yale 2014. 